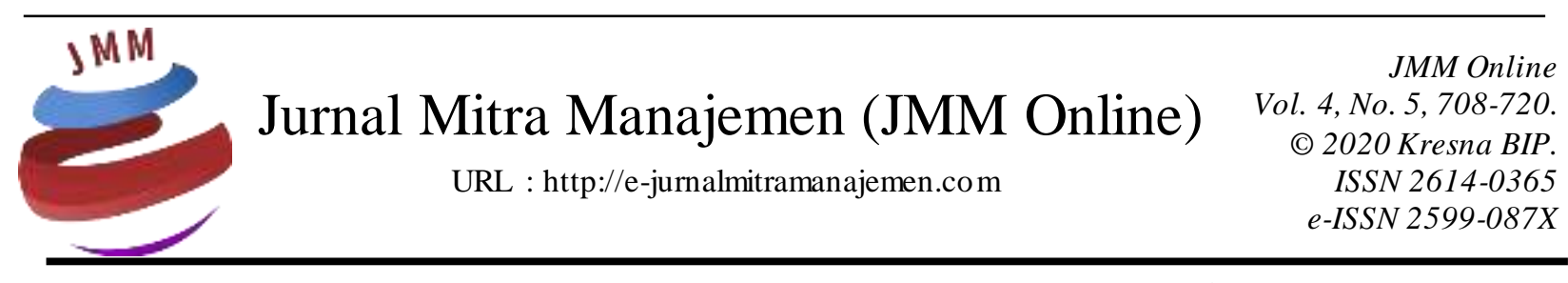

\title{
PENGARUH E-SERVICE QUALITY TERHADAP KEPUASAN DAN LOYALITAS PELANGGAN APLIKASI OVO
}

\section{Denaldi Danial Akhmadi 1), Erni Martini 2) Universitas Telkom}

INFORMASI ARTIKEL

Dikirim : 07 April 2020

Revisi pertama : 05 Mei 2020

Diterima : 16 Mei 2020

Tersedia online : 20 Mei 2020

Kata Kunci: AMOS, E-Service Quality, Kepuasan Pelanggan, Loyalitas Pelanggan, OVO, SEM

\section{Email :}

denaldiakhmadi@students.telkomuniversity. ac.id ${ }^{1)}$

ernimartini@telkomuniversity.ac.id ${ }^{2)}$

\section{ABSTRAK}

Upaya yang dilakukan OVO untuk bersaing dalam industri e-wallet salah satunya dengan memaksimalkan EService Quality yang diberikan kepada pelanggannya untuk menciptakan suatu kepuasan serta loyalitas pada aplikasi OVO. Tujuan dari penelitian ini adalah untuk melihat ap ak ah terdapat pengaruh E-Service Quality terhadap kepuasan dan loyalitas pelanggan aplikasi OVO, serta pengaruh kepuasan terhadap loyalitas pelanggan aplikasi OVO. Metode penelitian yang digunakan adalah metode kuantitatif. Teknik pengambilan data dilakukan dengan menyebarkan kuesioner secara online kepada pengguna aplikasi OVO sebanyak 400 responden di Indonesia. Teknik analisis data menggunakan SEM dengan AMOS 24. Hasil penelitian menunjukan bahwa E-Service Quality berpengaruh signifikan terhadap kepuasan dan loyalitas pelanggan aplikasi OVO. Serta, kepuasan berpengaruh signifikan terhadap loyalitas pelang gan aplikasi OVO. 


\section{PENDAHULUAN \\ Latar Belakang}

Kekuatan dari evolusi internet dan teknologi informasi telah mempengaruhi dan merubah kehidupan masyarakat sehari-hari. Dengan adanya perkembangan internet saat ini, gaya hidup masyarakat menjadi lebih cepat dan praktis. Internet dikenal sebagai media yang dapat memberikan dan menyampaikan informasi yang dibutuhkan kapanpun dan dimanapun. Dengan adanya kemajuan dan teknologi baru dalam segala bidang, internet saat ini telah menjadi akar untuk tiap bisnis dan praktiknya bagi suatu perusahaan (Tiwari et al., 2017). Penggunaan internet sebagai proses dalam berbisnis akan terus mengalami perkembangan yang membuat terciptanya berbagai macam inovasi yang dapat memudahkan proses komunikasi hingga proses bisnis (Laurent, 2016).

Keberadaan internet dan teknologi informasi pun meningkatkan bisnis jual beli online dan bisnis lainnya, salah satunya ialah transaksi secara elektronik (Nasution, 2019). Seiring dengan meningkatnya pengguna internet, popularitas smartphone di Indonesia pun mengalami kenaikan dengan banyaknya pengguna internet yang memilih menggunakan media smartphone untuk mengakses internet. Smartphone sudah menjadi hal yang diperluan untuk kehidupan masyarakat sehari-hari sebagai penghubung dengan seseorang ataupun melakukan bisnis hingga bertransaksi (Puriwat dan Tripopsakul, 2017). Maraknya pengguna internet dan smartphone telah memberikan perubahan dan peluang bisnis bagi sektor perusahaan dan bisnis khususnya pada sektor perbankan (Katadata, 2019). Hal tersebut dimanfaatkan untuk mengembangkan inovasi menarik yang dapat memberikan sebuah manfaat juga kemudahan dalam melakukan transaksi secara elektronik, salah satunya ialah inovasi mobile payment.

Pembayaran non-tunai merupakan kunci dari tren perkembangan mobile payment saat ini yang menjadikan daya tarik sehingga semakin banyak perusahaan yang berlomba untuk menawarkan solusi pembayaran bagi para pelanggannya. Dalam suatu bisnis perbankan, lingkungan keuangan yang semakin kompetitif dapat mendorong untuk mencari koneksi baru kepada para pelanggan mereka (Puriwat dan Tripopsakul, 2017). Adanya kenaikan pengguna mobile payment dan pasar yang luas di Indonesia dikarenakan banyaknya jumlah orang yang tidak memiliki rekening sehingga memilih untuk menggunaan teknologi $e$-wallet yang kini menjadi sebuah tren. E-wallet merupakan salah satu jenis mobile payment yang berkembang seiring dengan adanya kemunculan e-commerce dan marketplace di Indonesia. E-wallet di Indonesia begitu beragam yang ditawarkan oleh perbankan maupun non-perbankan yang memberikan kemudahan bagi penggunanya untuk melakukan transaksi melalui smartphone.

Dilihat dari banyaknya aplikasi $e$-wallet yang beragam, upaya yang perlu dilakukan oleh para pengusaha untuk bersaing dalam industri ini seperti membuat inovasi-inovasi yang memberikan kemudahan untuk para pelanggannya dan menciptakan sebuah kualitas layanan yang baik sehingga dapat tetap mempertahankan pangsa pasarnya. Kualitas layanan elektronik atau E-Service Quality secara luas yang dikemukakan oleh Parasuraman et al. (2005) ialah sejauh mana situs web dapat memberikan fasilitas dalam pembelian, pengiriman, serta transaksi secara efisien dan 
efektif. Selain itu, E-Service Quality dapat dimanfaatkan sebagai evaluasi dan penilaian pelanggan secara menyeluruh mengenai sebuah keunggulan dan kualitas pengiriman layanan pada marketplace ataupun internet (Lee dan Lin, 2005).

Dengan memberikan E-Service Quality yang baik akan berdampak pada kepuasan, karena kualitas layanan memiliki perang yang penting untu mengukur suatu kepuasan pelanggannya atas layanan yang diberikan oleh perusahaan. Definisi kepuasan atau satisfaction seperti yang disampaikan oleh Kotler dan Keller (2016) adalah perasaan senang atau kecewa seseorang yang dihasilkan dari membandingkan suatu kinerja ataupun hasil yang dirasakan terhadap produk atau layanan berdasarkan ekspektasinya. Jika pengalaman yang didapat jauh dari harapan maa pelanggan akan merasa tidak puas, sebaliknya jika harapan tersebut sesuai maka pelanggan akan merasa puas atau senang. Sama halnya seperti layanan yang diberikan oleh perusahaan, jika layanan tersebut sesuai dengan yang diharapkan maka pelanggan akan merasa puas atau senang. Menurut pendapat Tiwari (2017) kepuasan pelanggan ialah sebuah parameter yang sangat penting untu dijaga dalam masalah layanan online, karena sangat sulit untuk mengelola dan mempertahankan pelanggan yang loyal dengan layanan yang diberikan.

Loyalitas pelanggan dianggap sebagai salah satu faktor kunci suatu keberhasilan suatu bisnis untuk menciptakan keunggulan kompetitif dan keberlanjutan perusahaan dari waktu ke waktu (Puriwat dan Tripopsakul, 2017). Salah satu penentu utama dalam menciptakan loyalitas yaitu kepuasan pelanggan, selain itu adapun penentu yang dapat menciptakan loyalitas selain kepuasan yaitu biaya peralihan (switching cost). Menurut Tjiptono (2014) upaya yang dapat dilakukan supaya pelanggan menggunakan kembali suatu produk atau layanan seperti memberikan promosi secara terus-menerus dalam rangka memikat pelanggan untuk memakai kembali produk atau layanan tersebut.

Persaingan dalam dunia bisnis melalui kualitas layanan saat ini sudah mulai berkembang pada perusahaan di Indonesia, sehingga banyak perusahaan yang memanfaatkan media tersebut untuk mempertahankan eksistensi perusahaannya, salah satunya ialah bisnis $e$-wallet seperti aplikasi OVO. Aplikasi OVO merupakan sebuah aplikasi pembayaran yang instan dan aman yang dapat membuat segala kegiatan transaksi finansial penggunanya menjadi lebih mudah dan menyenangkan. E-wallet OVO berbasis aplikasi pada android dan juga ios, seiring berjalannya waktu OVO pun mulai berembang dengan pesat.

Upaya yang dilakukan oleh OVO untuk bersaing dalam industri $e$-wallet salah satunya dengan memaksimalkan E-Service Quality yang diberikan kepada penggunanya agar tercipta suatu kepuasan dan loyalitas pada aplikasi OVO. Tujuan dari penelitian ini adalah menganalisis pengaruh E-Service Quality terhadap kepuasan pelanggan aplikasi OVO, menganalisis pengaruh E-Service Quality terhadap loyalitas pelanggan aplikasi $\mathrm{OVO}$, serta menganalisis pengaruh kepuasan terhadap loyalitas pelanggan aplikasi OVO. 


\section{Rumusan Masalah}

Bedasarkan latar belakang yang telah dijabarkan diatas, maka peneliti membuat rumusan masalah sebagai berikut:

1. Apakah E-Service Quality berpengaruh terhadap Customer Satisfaction pengguna aplikasi OVO?

2. Apakah E-Service Quality berpengaruh terhadap Customer Loyalty pengguna aplikasi OVO?

3. Apakah Customer Satisfaction berpengaruh terhadap Customer Loyalty pengguna aplikasi OVO?

\section{Tujuan Penelitian}

Adapun tujuan penelitian pada penelitian ini ialah sebagai berikut:

1. Untuk mengetahui pengarus dari E-Service Quality terhadap Customer Satisfaction pengguna aplikasi OVO.

2. Untuk mengetahui pengaruh dari E-Service Quality terhadap Customer Loyalty pengguna aplikasi OVO.

3. Untuk mengetahui pengaruh Customer Satisfaction terhadap Customer Loyalty pengguna aplikasi OVO.

\section{KAJIAN PUSTAKA}

\section{E-Service Quality}

E-Service Quality merupakan teori yang dikembangkan dari service quality atau kualitas layanan yang diberikan maupun dilakukan pada jaringan internet. Kualitas layanan adalah salah satu kekuatan utama yang mendorong untuk keberlanjutan suatu bisnis dan sebuah keunggulan kompetitif pada perusahaan (Puriwat dan Tripopsakul, 2017). Seperti yang disampaikan oleh Santos (2003) EService Quality sebagai evaluasi dan penilaian secara menyeluruh dari pelanggan mengenai sebuah keunggulan dan kualitas yang disampaikan melalui internet. Selain itu, E-Service Quality secara luas adalah sejauh mana suatu web dapat memfasilitasi kegiatan belanja atau transaksi yang efisien dan efektif.

Dengan E-Service Quality yang disediakan oleh perusahaan tersebut akan memuaskan atau tidak memuaskan para pelanggan, karena kualitas layanan yang diberikan akan berpengaruh pada tingkat kepuasan pelanggan seperti yang disampaikan oleh (Lupiyoadi, 2013). Selain itu, pendapat lain menurut David (2018) ialah sebuah perusahaan perlu memberikan layanan secara berkualitas karena merupakan sumber keunggulan kompetitif. Pada perkembangan teknologi saat ini, kualitas layanan atau E-Service Quality menjadi sangat penting untuk mengukur kepuasan pelanggannya atas layana yang diberikan oleh perusahaan.

E-Service Quality memiliki lima dimensi yaitu sebagai berikut (Puriwat dan Tripopsakul, 2017) ; (1) Interface Design, kemudahan dan kenyamanan dalam menggunakan website atau aplikasi online. (2) Reliability, fungsi teknis dari suatu layanan atau situs yang dapat berjalan dengan benar dan lancar, dan kemanan layanan yang disediakan oleh perusahaan. (3) Responsiveness, kemampuan merespon atau menangani dengan cepat dalam memberikan bantuan kepada pelanggan jika ada masalah atau pertanyaan. (4) Trust, tingkat kepercayaan atau keyakinan pelanggan 
terhadap layanan yang disediakan dengan jelas dan benar oleh perusahaan. (5) Personalization, kemampuan dalam memberikan atau menyediakan layanan dan fitur secara personal untuk memenuhi kebutuhan pelanggan.

\section{Kepuasan Pelanggan}

Kepuasan atau satisfaction adalah perasaan senang atau kecewa seseorang yang dihasilkan dari membandingkan suatu kinerja ataupun hasil yang dirasakan terhadap produk atau layanan berdasarkan ekspektasi (Kotler dan Keller, 2016). Perusahaan perlu secara khusus memperhatikan tingkat kepuasan pelanggan mereka, karena dengan adanya internet memungkinkan pelanggan akan dengan cepat menyebarkan kata-kata baik ataupun buruk dari mulut ke mulut di seluruh dunia. Sedangkan menurut pendapat Tiwari (2017) kepuasan pelanggan merupakan sebuah parameter yang sangat penting untuk dijaga dalam masalah layanan online.

Kepuasan atau ketidakpuasan pelanggan sebagai respon terhadap evaluasi ketidaksesuaian (disconfirmation) yang dipersepsikan antara harapan awal sebelum pembelian dan kinerja aktual produk yang dipersepsikan setelah pemakaian (Tjiptono, 2014). Pada dasarnya suatu kepuasan atau ketidakpuasan pelanggan atas suatu produk atau layanan akan berpengaruh pada pola perilaku selanjutnya. Hal tersebut ditunjukan pelanggan setelah proses pembelian terjadi, apabila mereka merasa puas maka mereka akan menunjukan besarnya kemungkinan untuk menggunaan kembali produk tersebut dan merekomendasikan produk tersebut kepada orang lain.

\section{Loyalitas Pelanggan}

Loyalitas pelanggan didefinisikan sebagai suatu komitmen yang dimiliki untuk membeli atau menggunakan produk maupun layanan yang sama (Kotler dan Keller, 2016). Pelanggan merupakan seseorang yang berulang kali pergi ke tempat yang sama untuk memuaskan keinginannya dengan mendapatkan dan membayar produk atau layanan tersebut. Loyalitas pelanggan pun dapat diartikan sebagai orang yang membeli suatu produk atau layanan, terutama mereka yang membeli secara teratur dan berulang seperti yang dikemukakan oleh (Nasution, 2019). Loyalitas pelanggan dianggap sebagai salah satu kunci suatu keberhasilan bisnis untuk menciptakan keunggulan kompetitif dan keberlanjutan perusahaan dari waktu ke waktu (Puriwat dan Tripopsakul, 2017).

Penentu utama dalam menciptakan loyalitas yaitu kepuasan pelanggan dan biaya peralihan (Beerli, 2004). Loyalitas pelanggan untuk memakai kembali suatu produk atau layanan bisa merupakan hasil dari upaya promosi secara terus-menerus dalam rangka memikat dan membujuk pelanggan untuk tetap menggunakan produk tersebut (Tjiptono, 2014). Selain itu, loyalitas pelanggan adalah "komitmen yang dipegang teguh untuk membeli ulang atau berlangganan dengan produk atau jasa yang disukai secara konsisten di masa mendatang, sehingga menimbulkan pembelian merek atau rangkaian merek yang sama secara berulang, meskipun pengaruh situasional dan upaya pemasaran berpotensi untuk menyebabkan perilaku beralih merek". 


\section{Kerangka Pemikiran}

Berdasarkan penjelasan kajian teoritis diatas, maka kerangka konsep dan hipotesis yang digunakan dalam penelitian ini diadaptasi dari Puriwat dan Tripopsakul (2017) sebagai berikut:

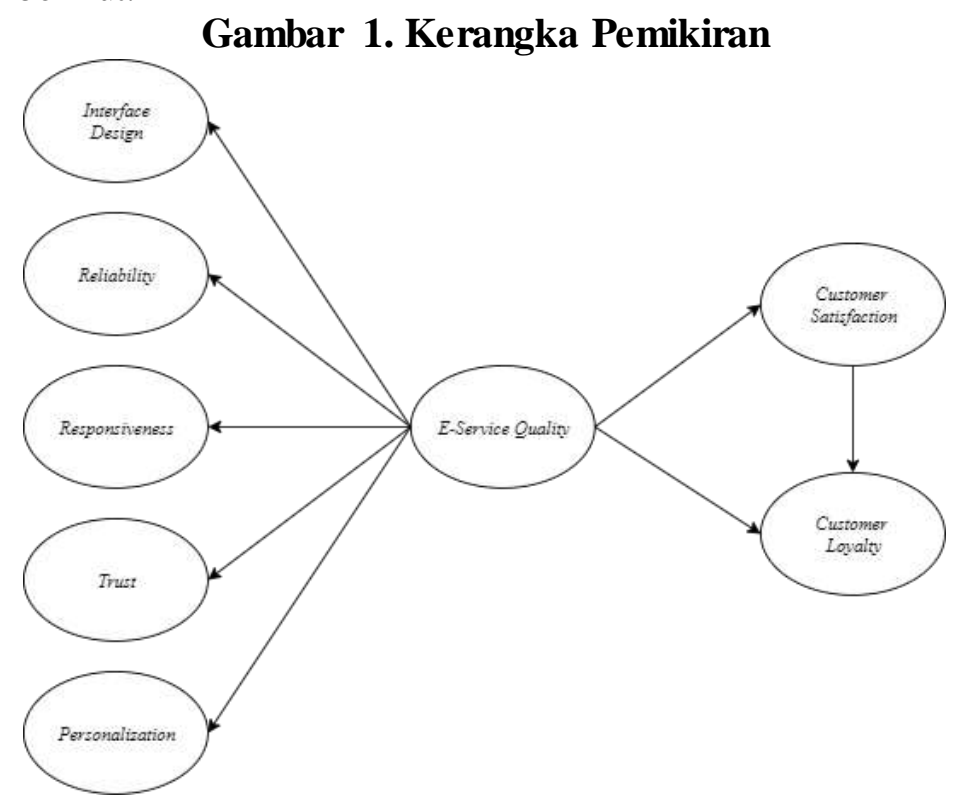

Sumber: Puriwat dan Tripopsakul (2017).

\section{Hipotesis Penelitian}

Pada penelitian ini terdapat tiga hipotesis yang dapat dirumuskan sebagai berikut:

H1 : Terdapat pengaruh signifikan dari E-Service Quality terhadap Customer Satisfaction pada pengguna aplikasi OVO.

H2 : Terdapat pengaruh signifikan dari E-Service Quality terhadap Customer Loyalty pada pengguna aplikasi OVO.

H3 :Terdapat pengaruh signifikan dari Customer Satisfaction terhadap Customer Loyalty pada pengguna aplikasi OVO.

H4 : Customer Satisfaction memediasi pengaruh E-Service Quality terhadap Customer Loyalty pada pengguna aplikasi OVO.

\section{METODE PENELITIAN}

\section{Jenis Penelitian}

Metode yang digunakan dalam penelitian ini ialah kuatitatif. Metode kuantitatif adalah metode penelitian yang dapat digunakan untuk meneliti pada sebuah populasi atau sampel tertentu, pengumpulan data menggunakan teknik pengambilan sampel yang dilakukan secara random, dengan pengumpulan datanya menggunakan instrument penelitian, analisis data bersifat kuantitatif atau statistik dengan tujuan untuk menguji hipotesis yang telah ditetapkan (Sugiyono, 2016). Penelitian mengenai pengaruh E-Service Quality pada kepuasan dan loyalitas pelanggan aplikasi OVO menggunakan metode kuantitatif dengan strategi survei. Strategi survei merupakan sistem untuk pengumpulan sebuah informasi dari atau seseorang untuk 
menggambarkan atau menjelaskan tentang pengetahuan, sikap, dan perilaku (Sekaran dan Bougie, 2017).

Menurut Indrawati (2015) populasi adalah keseluruah kelompok ataupun orang yang menarik untuk dilakukan sebuah penelitian. Selain itu, populasi merupakan suatu wilayah generalisasi yang terdiri dari objek atau subjek yang memiliki kualitas dan karakteristik tertentu yang ditetapkan oleh penulis untuk dipelajari dan ditarik kesimpulannya (Sugiyono, 2016). Dalam penelitian ini, populasi yang digunakan adalah pengguna aplikasi OVO di Indonesia. Sampel adalah bagian dari jumlah dan karakteristik yang dimiliki oleh suatu populasi (Sugiyono, 2014). Sedangkan menurut Sekaran dan Bougie (2017) sampel merupakan bagian dari suatu populasi yang terdiri atas sejumlah anggota yang dipilih dari sebuah populasi. Dalam penelitian ini, penulis mencari responden sesuai dengan yang disyaratkan yaitu pengguna yang menggunakan aplikasi OVO dan melakukan transaksi dengan OVO. Ukuran sampel pada penelitian ini sebanyak 400 responden pengguna aplikasi OVO.

Teknik pengambilan data yang dilakukan oleh penulis dengan menggunakan kuesioner yang disebarkan secara online dan menggunakan skala likert berskala satu hingga lima. Kuesioner yang telah dibuat secara online kemudian disebarkan melalui media sosial sehingga dapat memudahkan responden dalam mengisi kuesioner tersebut. Kuesioner merupakan teknik pengumpulan data yang dilakukan dengan cara memberikan seperangkat pernyataan atau pertanyaan tertulis kepada responden untuk dijawab.

\section{Tempat, Waktu dan Objek Penelitian}

Peneliti melakukan penelitian ini kepada seluruh pengguna aplikasi OVO yang ada di seluruh Indonesia, karena peneliti ingin meneliti dengan cakupan yang lebih luas. Objek penelitian yang digunakan dalam penelitian ini yaitu aplikasi OVO. Penelitian ini berfokus pada pengguna aplikasi OVO yang ada di Indonesia. Selain itu, penelitian ini pun dilakukan pada bulan September 2019 hingga Februari 2020.

\section{Operasionalisasi Variabel}

Variabel yang digunakan dalam penelitian ini adalah sebagai berikut:

1. Variabel Independen

Variabel independent (bebas) adalah variabel yang mempengaruhi atau yang menjadi sebab perubahannya atau timbulnya variabel dependen (terikat). Pada penelitian ini yang menjadi variabel independent (bebas) adalah E-Service Quality (X).

2. Variabel Dependen

Variabel dependen (terikat) adalah variabel yang dipengaruhi atau yang menjadi akibat karena adanya variabel bebas. Pada penelitian ini yang menjadi variabel dependen (terikat) adalah Kepuasan dan Loyalitas Pelanggan (X).

\section{Teknik Pengumpulan Data}

Dalam penelitian ini penulis mengumpulkan data-data dengan cara menyebarkan kuesioner secara online kepada responden. Selain itu, untuk 
pengumpulan data sekunder digunakan data dari buku, jurnal-jurnal, karya ilmiah, situs internet, serta hasil penelitian terdahulu.

\section{Sumber Data}

Dalam penelitian ini, sumber data yang diteliti oleh penulis adalah data primer yang bersifat kuantitatif, yaitu dengan cara menyebarkan kuesioner kepada pengguna Aplikasi OVO di Indonesia.

\section{Teknik Analisis Data}

1. Uji Validitas dan Reliabilitas

Dalam penelitian ini menggunakan teknik Structural Equation Model (SEM) yang merupakan model statistika yang menjelaskan mengenani hubungan antara beberapa variabel, sehingga dapat meneliti hubungan timbal balik yang dinyatakan dalam bentuk persamaan. Teknik analisis data yang digunakan merupakan salah satu teknik dari SEM yaitu Confirmatory Factor Analysis (CFA) yang berguna untuk menguji variabel E-Service Quality, Customer Satisfaction, dan Customer Loyalty yang terukur dengan baik dalam menggambarkan suatu bilangan dari suatu faktor atau konstrak. Uji validitas menurut Sugiyono (2016) berfungsi untuk mengukur instrument yang dapat digunakan untuk mengukur apa yang seharusya diukur, pada penelitian ini CFA digunakan untuk menguji loading factor pada tiap indikator atau dimensi yang ada. Sedangkan reliabilitas adalah sebuah instrument yang jika digunakan secara berulang kali untuk mengukur sebuah objek yang sama akan menghasilkan data yang sama (Sugiyono, 2016).

2. Structural Equation Model (SEM)

Penelitian ini menggunakan teknik Structural Equation Modeling (SEM) yaitu Confirmatory Factor Analysis (CFA). Menurut Hair et al. (2014 : 546) menyampaikan Structural Equatin Model (SEM) merupakan model statistika yang menjelaskan mengenai hubungan antara beberapa variabel, sehingga dapat meneliti hubungan timbal balik yang dinyatakan dalam bentuk persamaan. Selain itu, persamaan disini menggambarkan seluruh hubungan antara konstruk variabel dependen dan independen yang terlibat dalam analisis tersebut. Dalam penelitian ini tahapan yang dilakukan untuk pengujian data yang didapat yaitu SEM, Goodness of Fit $(G o F)$, dan uji hipotesis.

3. Pengujian Hipotesis

Pada penelitian ini, pengujian hipotesis dilakukan dengan menggunakan nilai $t$-value untuk menguji hipotesis secara parsial dengan menggunakan tingkat signifikansi 5\% atau 0,05. Nilai $t$-value merupakan nilai Critical Ratio (CR) dari overall fit model. Jika nilai $\mathrm{CR} \geq 1,966$ atau nilai probabilitas $(\mathrm{P}) \leq 0,05$ maka hipotesis diterima.

\section{HASIL PENELITIAN DAN PEMBAHASAN \\ Karakteristik Responden}

Penyebaran kuesioner kepada 400 orang didapatkan hasil karakteristik responden bahwa jumlah perempuan diperoleh lebih banyak dibandingkan dengan laki-laki yaitu perempuan $(72,5 \%)$ antara usia $18-24$ tahun $(77,3 \%)$ yang merupakan 
generasi milenial yang gemar dengan sesuatu yang praktis dan instan dengan pendidikan terakhir sebagai mahasiswa $(60,8 \%)$ dan sudah menggunakan layanan OVO selama 1 tahun dengan persentase paling banyak (40,3\%). Karakteristik responden berdasarkan tingkat pengalaman belanja online. Responden dengan tingkat pengalaman belanja online pemula sebanyak 118 orang (30,5\%). Dengan tingkat pengalaman belanja online menegah 207 orang (53,5). Sedangkan responden dengan tingkat belanja online ahli sebanyak 62 orang( 16\%). Karakteristik responden berdasarkan frekuensi belanja online per tahun. Responden dengan frekuensi belanja online kurang dari 3 kali per tahun sebanyak 77 (19,9\%). Responden dengan frekuensi belanja online 3-5 kali per tahun $128(33,1 \%)$. Responden deengan frekuensi belanja 5-10 kali per tahun sebanyak 117 orang (30,2\%). Sedangkan responden dengan frekuensi belanja online lebih dari 10 kali per tahun sebanyak 65 orang $(16,8 \%)$..

\section{Uji Validitas dan Reliabilitas}

Tabel 1. Uji Validitas dan Reliabilitas

\begin{tabular}{|c|c|c|c|c|}
\hline Variabel & Nama Item & Loading Factor & AVE & $\begin{array}{c}\text { Cronbach } \\
\text { Alpha }\end{array}$ \\
\hline \multirow{3}{*}{ Interface Design } & ID1 & 0,727 & \multirow{3}{*}{0,770} & \multirow{3}{*}{0,779} \\
\hline & ID2 & 0,945 & & \\
\hline & ID3 & 0,943 & & \\
\hline \multirow{4}{*}{ Reliability } & RE1 & 0,953 & \multirow{4}{*}{0,777} & \multirow{4}{*}{0,823} \\
\hline & RE2 & 0,774 & & \\
\hline & RE3 & 0,907 & & \\
\hline & RE4 & 0,884 & & \\
\hline \multirow{3}{*}{ Responsiveness } & RS1 & 0,809 & \multirow{3}{*}{0,662} & \multirow{3}{*}{0,851} \\
\hline & RS2 & 0,905 & & \\
\hline & RS3 & 0,716 & & \\
\hline \multirow{2}{*}{ Trust } & TR1 & 0,944 & \multirow{2}{*}{0,776} & \multirow{2}{*}{0,900} \\
\hline & TR2 & 0,814 & & \\
\hline \multirow{3}{*}{ Personalization } & PR1 & 0,947 & \multirow{3}{*}{0,757} & \multirow{3}{*}{0,881} \\
\hline & PR2 & 0,923 & & \\
\hline & PR3 & 0,724 & & \\
\hline \multirow{3}{*}{ Customer Satisfaction } & CS1 & 0,788 & \multirow{3}{*}{0,668} & \multirow{3}{*}{0,881} \\
\hline & $\overline{\mathrm{CS} 2}$ & 0,899 & & \\
\hline & $\mathrm{CS} 3$ & 0,759 & & \\
\hline \multirow{3}{*}{ Customer Loyalty } & CL1 & 0,881 & \multirow{3}{*}{0,771} & \multirow{3}{*}{0,800} \\
\hline & CL2 & 0,932 & & \\
\hline & CL3 & 0,819 & & \\
\hline
\end{tabular}

Sumber : Hasil Penelitian, diolah (2020)

Berdasarkan hasil uji validitas pada tabel 1 AVE dan CR untuk variabel $E$ Service Quality, Customer Satisfaction, dan Customer Loyalty. Hasil dari loading factor dari masing-masing variabel tersebut menunjukkan bahwa nilai yang dihasilkan 
memiliki nilai ideal diatas 0,7 atau lebih. Sedangkan untuk AVE menghasilkan nilai yang baik dengan nilai diatas 0,5 atau lebih. Sama halnya dengan CR untuk masingmasing variabel memiliki nilai yang disarankan oleh (Hair et al., 2014) yaitu diatas 0,7 .

\section{Pengujian Hipotesis}

Tabel 2. Hasil Uji Hipotesis

\begin{tabular}{|c|c|c|c|c|c|c|c|}
\hline \multirow{2}{*}{\multicolumn{3}{|c|}{ ECom }} & Estimate & S.E. & C.R. & $\mathrm{P}$ & Keterangan \\
\hline & & & ,930 &, 042 & 24,874 & $* * *$ & H1 diterima \\
\hline \multirow{2}{*}{$\begin{array}{l}\text { CustSatis } \\
\text { CustLoyal } \\
\text { CustLoyal }\end{array}$} & $<---$ & EServQual & ,805 & ,064 & 14,085 & $* * *$ & $\mathrm{H} 2$ diterima \\
\hline & $<---$ & CustSatis & ,179 & ,052 & 3,403 & $* * *$ & H3 diterima \\
\hline
\end{tabular}

Sumber : Hasil Penelitian, diolah (2020)

Hasil uji hipotesis tersebut menunjukkan hasil dari pengujian hipotesis dengan software AMOS 24 yang menunjukkan nilai Critical Ratio (C.R) dan probability (P). Berdasarkan pada Tabel 4.5 dapat disimpulkan bahwa hipotesis kesatu (H1), hipotesis kedua (H2), dan hipotesis ketiga (H3) pada penelitian ini secara keseluruhan ialah diterima. Untuk hipotesis kesatu (H1) yaitu E-Service Quality memiliki pengaruh signifikan pada Customer Satisfaction pengguna aplikasi OVO.

Pada penelitian ini hipotesis kesatu $(\mathrm{H} 1)$ diterima karena memiliki nilai Critical Ratio atau T Hitung sebesar 24,874 yang lebih besar dibandingkan dengan nilai C.R sebesar 1,96, selain itu angka probability (P) pada hipotesis kesatu menghasilkan nilai $\mathrm{P}<0,05$ ditunjukkan dengan tanda $(* * *)$ yang berarti signifikan memiliki hubungan. hipotesis kedua $(\mathrm{H} 2)$ yaitu E-Service Quality terhadap Customer Loyalty pengguna aplikasi OVO. Selanjutnya untuk hipotesis kedua (H2) diterima karena memiliki nilai Critical Ratio atau T Hitung sebesar 14,085 yang lebih besar dibandingkan dengan nilai C.R sebesar 1,96, selain itu angka probability (P) pada hipotesis kedua menghasilkan nilai $\mathrm{P}<0,05$ ditunjukkan dengan tanda (***) yang berarti signifikan memiliki hubungan. Sedangkan untuk hipotesis ketiga (H3) yaitu Customer Satisfaction terhadap Customer Loyalty pengguna aplikasi OVO diterima karena memiliki nilai Critical Ratio atau T Hitung sebesar 3,403 yang lebih besar dibandingkan dengan nilai C.R sebesar 1,96, selain itu angka probability (P) pada hipotesis ketiga menghasilkan nilai $\mathrm{P}<0,05$ ditunjukkan dengan tanda $(* * *)$ yang berarti signifikan memiliki hubungan. Berdasarkan hasil pengujian hipotesis yang telah dilakukan dapat disimpulkan bahwa E-Service Quality memiliki pengaruh yang signifikan kepada kepuasan dan loyalitas pelanggan aplikasi OVO.

\section{Pembahasan}

Untuk hipotesis kesatu (H1) yaitu E-Service Quality memiliki pengaruh signifikan pada Customer Satisfaction pengguna aplikasi OVO. Pada penelitian ini hipotesis kesatu (H1) diterima karena memiliki nilai Critical Ratio atau $\mathrm{T}$ Hitung sebesar 24,874 yang lebih besar dibandingkan dengan nilai C.R sebesar 1,96, selain itu angka probability $(\mathrm{P})$ pada hipotesis kesatu menghasilkan nilai $\mathrm{P}<0,05$ ditunjukkan dengan tanda $(* * *)$ yang berarti signifikan memiliki hubungan. Dengan diterimanya hipotesis kesatu (H1) hal ini dapat diartikan bahwa E-Service Quality berpengaruh 
secara signifikan terhadap Customer Satisfaction pengguna aplikasi OVO. Hasil penelitian ini sejalan dengan penelitian yang dilakukan oleh Puriwat dan Tripopsakul (2017) yang menghasilkan bahwa E-Service Quality memiliki pengaruh signifikan terhadap Customer Satisfaction. Bahwa dengan sejalannya hasil penelitian yang dilakukan oleh penulis ini dapat memperkuat hasil yang diperoleh dari penelitianpenelitian sebelumnya.

Untuk hipotesis kedua (H2) yaitu E-Service Quality terhadap Customer Loyalty pengguna aplikasi OVO. Pada penelitian ini hipotesis kedua (H2) diterima karena memiliki nilai Critical Ratio atau T Hitung sebesar 14,085 yang lebih besar dibandingkan dengan nilai C.R sebesar 1,96, selain itu angka probability (P) pada hipotesis kedua menghasilkan nilai $\mathrm{P}<0,05$ ditunjukkan dengan tanda (***) yang berarti signifikan memiliki hubungan. Dengan diterimanya hipotesis kedua (H2) hal ini dapat diartikan bahwa E-Service Quality berpengaruh secara signifikan terhadap Customer Loyalty pengguna aplikasi OVO. Hasil penelitian ini sejalan dengan penelitian yang dilakukan oleh Puriwat dan Tripopsakul (2017) karena pada penelitiannya menghasilkan bahwa E-Service Quality berpengaruh signifikan terhadap Customer Loyalty. Sehingga penelitian ini dapat memperkuat hasil yang diperoleh dari penelitian-penelitian sebelumnya.

Untuk hipotesis ketiga (H3) yaitu Customer Satisfaction terhadap Customer Loyalty pengguna aplikasi OVO. Pada penelitian ini hipotesis ketiga (H3) diterima karena memiliki nilai Critical Ratio atau T Hitung sebesar 3,403 yang lebih besar dibandingkan dengan nilai C.R sebesar 1,96, selain itu angka probability (P) pada hipotesis ketiga menghasilkan nilai $\mathrm{P}<0,05$ ditunjukkan dengan tanda (***) yang berarti signifikan memiliki hubungan. Dengan diterimanya hipotesis ketiga (H3) hal ini dapat diartikan bahwa Customer Satisfaction berpengaruh secara signifikan terhadap Customer Loyalty pengguna aplikasi OVO. Hasil penelitian ini sejalan dengan penelitian yang dilakukan oleh Puriwat dan Tripopsakul (2017) yang menghasilkan bahwa Customer Satisfaction memiliki pengaruh signifikan terhadap Customer Loyalty. Maka dari itu, hasil dari penelitian ini dapat memperkuat hasil penelitian yang diperoleh dari penelitian-penelitian sebelumnya.

Hasil dari penelitian ini mendapatkan hipotesis keempat (H4) mengenai peran kepuasan memediasi pengaruh kualitas layanan terhadap loyalitas pelanggan pada aplikasi OVO. Dari hasil pengujian didapatkan hasil bahwa E-Service Quality berpengaruh langsung (direct) terhadap loyalitas pelanggan dengan hasil sebesar 0,805 dilihat dari nilai Standardized Regression Weight, sementara untuk pengaruh tidak langsung (indirect) sebesar 0,166 yang dilihat dari nilai Standardized Indirect Effects. Dari hasil tersebut dapat disimpulkan bahwa E-Service Quality memiliki pengaruh langsung kepada loyalitas melalui kepuasan karena hasil yang didapatkan menyatakan nilai Standardized Regression Weight (direct) lebih besar dibandingkan dengan nilai Standardized Indirect Effects (indirect), dari hasil tersebut berarti sebuah kepuasan seorang pelanggan tidak memediasi E-Service Quality terhadap loyalitas pelanggan aplikasi OVO. 


\section{KESIMPULAN DAN SARAN \\ Kesimpulan}

berikut:

Berdasarkan penelitian yang telah dilakukan dapat ditarik kesimpulan sebagai

1. Berdasarkan dari hasil penelitian ini dapat diketahui bahwa E-Service Quality memiliki pengaruh yang signifikan terhadap Customer aplikasi OVO.

2. Berdasarkan dari hasil penelitian ini dapat diketahui bahwa E-Service Quality memiliki pengaruh yang signifikan terhadap Customer Loyalty aplikasi OVO.

3. Selanjutnya, berdasarkan hasil penelitian ini dapat diketahui bahwa Customer Satisfaction memiliki pengaruh yang signifikan terhadap Customer Loyalty aplikasi OVO.

4. Selanjutnya, berdasarkan hasil penelitian ini dapat diketahui bahwa E-Service Quality memiliki pengaruh langsung kepada Customer Loyalty melalui Customer Satisfaction aplikasi OVO.

\section{Saran}

Berdasarkan dari kesimpulan yang didapatkan maka kesimpulan tersebut dapat dijadikan sebuah saran bagi perusahaan terkait yaitu OVO sebagai berikut:

1. Hasil pada penelitian ini menunjukkan bahwa dimensi E-Service Quality mempengaruhi Customer Satisfaction pada aplikasi OVO, maka perusahaan disarankan untuk menjaga kualitas aplikasi OVO seperti melakukan bugs fixing secara berkala guna menjaga aplikasinya dapat berjalan dengan lancar dan terbebas dari kesalahan (error) sehingga penggunanya dapat menikmati layanan tersebut tanpa adanya hambatan. Selain itu perusahaan pun perlu mendengarkan keluhankeluhan dari penggunanya, serta perusahaan perlu menangani suatu masalah dengan serius sehingga perusahaan dapat memperbaiki kualitas layanannya menjadi lebih baik dan menciptakan kepuasan pada pengguna aplikasi OVO yang terbebas dari gangguan.

2. Hasil penelitian ini menunjukkan dimensi E-Service Quality mempengaruhi Customer Loyalty pada aplikasi OVO, maka perusahaan disarankan selain memberikan promo atau cashback yang menarik bagi pelanggannya, OVO pun perlu menciptakan fitur yang berbeda dengan aplikasi e-money lainnya dan juga menarik bagi penggunanya sehingga dapat digunakan secara berkelanjutan dan memberikan manfaat. Selanjutnya, pihak OVO dapat memberikan sebuah reward untuk pelanggan yang sering melakukan transaksi menggunakan aplikasi OVO, sehingga dapat membentuk sebuah loyalitas yang baik bagi penggunanya.

3. Berdasarkan hasil penelitian ini menunjukkan dimensi Customer Satisfaction memiliki pengaruh kepada Customer Loyalty pada aplikasi OVO, maka dari itu perusahaan disarankan untuk mempertahankan layanan-layanan yang dimiliki, namun pihak OVO pun perlu memperhatikan kebutuhan ataupun keinginan penggunanya sehingga dapat memberikan layanan yang sesuai atau ideal dengan apa yang dibutuhkan oleh pelanggan aplikasi OVO. Dengan upaya demikian mereka akan terpuaskan oleh layanan yang diberikan sehingga pengguna yang merasa puas akan tercipta rasa ingin menggunakan kembali layanan tersebut, serta 
pelanggan dapat merekomendasikan aplikasi OVO kepada orang terdekat maupun orang lain.

\section{DAFTAR PUSTAKA}

Beerli, A., Martin, D. J., dan Quintana, A. 2004. A Model of Customer Loyalty In The Retail Banking Marketing. European Journal of Marketing, 38(1/2), 253-275.

Parasuraman, A., Zeithaml, V., dan Malhotra, A. 2005. E-S-Qual A Multiple-Item Scale for Assessing Electronic Service Quality. Journal of Service Research, 7(3) , 213-233.

David. 2018. Pengaruh E-Service Quality Terhadap Loyalitas Pelanggan Melalui Kepuasan Pelanggan Pada Transportasi Online Grab. AGORA, 6(2).

Laurent, F. 2016. Pengaruh E-Service Quality Terhadap Loyalitas Pelanggan. AGORA , 95-100.

Tjiptono, F. 2014. Pemasaran Jasa - Prinsip, Penerapan, dan Penelitian (Ed.1). Yogyakarta: Andi.

Lee, G., dan Lin H. 2005. Customer Perceptions of E-Service Quality in Online Shopping. International Journal of Retail \& Distribution Management, 33(2), 161-176.

Nasution H., Fauzi A., dan Rini S. E. 2019. The Effect of E-Service Quality on ELoyalty Through E-Satisfaction on Students of Ovo Application Users. European Journal of Management and Marketing Studies, 4(1), 146-162.

Widowati, H. 2018. Teknologi Jadi Prioritas Transformasi Bisnis Perbankan. [online]. https://katadata.co.id/berita/2018/02/27/teknologi-jadi-prioritas-transformasibisnis-perbankan [4 Oktober 2019].

Indrawati. 2015. Metode Penelitian Manajemen dan Bisnis : Konvergensi Teknologi Komunikasidan Informasi. Bandung: Refika Aditama.

Hair, J. F., Black, W. C., Babin, B. J., dan Anderson, R. E. 2014. Multivariate Data Analysis. Edinburgh Gate, Harlow: Pearson Education Limited.

Santos, J. 2003. E-Service Quality: A Model Of Virtual Service Quality Dimensions. Management Service Quality, 13(3), 233-246.

Kotler, P., dan Keller, K. 2016. Marketing Management (15th ed). Edinburgh Gate, Harlow, England: Pearson Education.

Tiwari, P., Tiwari, K. S., dan Singh, P. T. 2017. Measuring The Effect of E-Service Quality In Online Banking. Prestige International Journal of Management \& ITSanchayan , 43-52.

Lupiyoadi, R. 2013. Manajemen Pemasaran Jasa: Berbasis Kompetensi (3rd ed.). Jakarta, Indonesia: Salemba Empat.

Sekaran, U., dan Bougie, R. 2017. Metode Penelitian untuk Bisnis (6th ed). Jakarta Selatam: Salemba Empat.

Sugiyono. 2016. Metode Penelitian Pendidikan (Pendekatan Kuantitatif, Kualitatif, dan $R \& D)$. Bandung: ALFABETA.

Puriwat, W., dan Tripopsakul, S. 2017. The Impact of E-Service Quality on Customer Satisfaction and Loyalty in Mobile Banking Usage: Case Study of Thailand. Polish Journal of Management Studies , 183-193. 